\title{
Log-based prediction of pore pressure and its relationship to compressional velocity, shear velocity and Poisson's ratio in gas reservoirs; Case study from selected gas wells in Iran
}

\author{
E. R. Nikou, H. Aghaei, M. Ghaedi, H. Jafarpour \\ Petroleum Engineering Department, School of Chemical and Petroleum Engineering, Shiraz \\ University, Fars, Iran
}

\begin{abstract}
A precise identification of pore fluid pressure (PP) is of great significance, specifically, in terms of drilling safety and reservoir management. Despite numerous work have been carried out for prediction of PP in oil reservoirs, but there still exists a tangible lack of such work in gas hosting rocks. The present study aims to discuss and evaluate the application of a number of existing methods for prediction of PP in two selected giant carbonate gas reservoirs in south Iran. For this purpose, PP was first estimated based on the available conventional log data and later compared with the PP suggested by Reservoir Formation Test (RFT) and other bore data. At the end, it has been revealed that while PP prediction is highly dependent on the type of litho logy in carbonates, the effect of fluid type is negligible. Moreover, the velocity correlations work more efficiently for the pure limestone/dolomite reservoirs compared with the mixed ones.
\end{abstract}

\section{Introduction}

Pore Pressure (PP), that is the pressure inside pore spaces of a rock, is known as one of the key parameters that must be well studied and predicted in order to optimize the formation evaluation and drilling programs [1-3].Equivalent depth methods [4], the ratio method [5], Eaton's method [6], resistivity method with depth-dependent Normal Compaction Trendline (NCT), sonic method with depth-dependent and effective stress method [7] are examples of methods commonly used to determine the PP.

It has been shown that PP is foreseeable from variation in specific rock physics properties, such as, sonic velocity and electronic resistivity [8]. However, despite of extensive efforts in development of several approaches for PP prediction but difficulties and uncertainties in carbonate formations persist mainly due to their significant multi-scale heterogeneities [9].

In fact, the conventional PP prediction methods may not be reliable to be used for carbonate rocks mainly because their porosity is highly affected bypost-diagenesis chemical and cementation processes [10].Subsequently, the dominance of lithification by diagenesis 
over the one developed by compaction is the reason why acoustic velocity in carbonates show no clear correlation with increasing depth [11].

As mentioned by [2], the PP prediction process based on elastic wave data must follow three main steps including data acquisition and analysis, linking the elastic wave attributes to either effective stress (PE) or PP through a proper geophysical model, and finally estimation of the PE or PP.

The present research aims to apply elastic moduli PErelation to predict the PP in two selected carbonate gas reservoirs.

\section{Methodology}

Data were collected from two giant carbonate gas reservoirs, here named as AA and BB, located in south-Iran. Table 1 presents further details from the target reservoirs.

Table 1. Lists basic information of selected carbonate reservoirs as the focus of this study.

\begin{tabular}{|c|c|c|c|}
\hline \multirow{2}{*}{ Reservoir } & Depth & \multirow{2}{*}{ Main Lithology } & Porosity \\
\hline & $\mathrm{m}$ & & percent \\
\hline AA & $2841-3085$ & $\begin{array}{l}\text { Mixed dolomite and } \\
\text { limestone (dominantly } \\
\text { dolomite in the upper part) }\end{array}$ & $4-8$ \\
\hline BB & $2370-2525$ & $\begin{array}{l}\text { Mixed dolomite and } \\
\text { limestone }\end{array}$ & $8-12$ \\
\hline
\end{tabular}

The PP prediction modelling was based on the availablesonic (DT) and density (RHOB) logs as well as reported Reservoir Formation Test (RFT) data.

Note that transient time (DT) data were converted into $\mathrm{V}_{\mathrm{p}}$ using the following equation:

$\mathrm{Vp}[\mathrm{m} / \mathrm{s}]=1 / \mathrm{DT}(1)$

Moreover, compressional and shear velocities (Vp\& Vs) were estimated based on a number of well-known existing correlations developed by [12] and [13] as explained below.

\subsection{Castagna et al. (1993) correlation}

The $V_{p}$ values resulted from Eq.1 were used to estimate the Vs according to the following equations as suggested by [12] for dolomite (Eq. 2) and limestone (Eq. 3):

$$
\begin{gathered}
V_{s}=-0.05509 \times\left(V_{p} \times 1000\right)^{2}+1.0168 \times\left(V_{p} \times 1000\right)-1.0305 \\
V_{s}=0.583 \times\left(V_{p} \times 1000\right)-0.07776
\end{gathered}
$$

Where $V_{p}$ and $V_{s}$ are in $[\mathrm{m} / \mathrm{s}]$

\subsection{Anselmati and Eberli (1993) correlation}

$V_{p}$ and $V_{s}$ were also estimated based on the density log data and using the following equations as proposed by [13]: 


$$
\begin{gathered}
V_{p}=524(\text { density })^{2.48} \\
V_{s}=199(\text { density })^{2.84}
\end{gathered}
$$

Where $V_{p}$ and $V_{s}$ are in $[\mathrm{m} / \mathrm{s}]$ and density is in $\left[\mathrm{g} / \mathrm{cm}^{3}\right]$.

It should be noted that both of the [12] and [13] equations were specifically developed for carbonate reservoirs and attention must be paid in case of siliciclastic or mixed carbonate-siliciclastic reservoir rocks.

\subsection{Effective pressure modeling}

The above-mentioned estimated velocities were then used to determine the Poisson's ratio. It worth mentioning that Poisson's ratio can be estimated based on static and/or dynamic methods [14]. In the former method, rock specimen is affected by uniaxial or tri-axial load until the failure occurs and the recorded stress, lateral and axial deformations will be used to determine the Poisson's ratio. In dynamic method the Poisson's ratio will determined based on the measured $\mathrm{Vp}$ and Vsand using the following equations as suggested by:

$$
v=\frac{\frac{1}{2} v_{p}^{2}-V_{s}^{2}}{V_{p}^{2}-V_{s}^{2}}
$$

Where $v$ is the Poisson's ratio.

Next, the overburden pressure $(\sigma v)$ was estimated based on the depth, density and sonic $\log$ data and using the following equation as suggested by [2]:

$$
\sigma v=g \int_{0}^{h} \rho(z) d z
$$

Where $\mathrm{g}$ is the gravity acceleration is in $[\mathrm{Nkg}]$ and $\rho$ is the rock bulk density is in $\left[\mathrm{kg} / \mathrm{m}^{3}\right]$ at depth $\mathrm{z}[\mathrm{m}]$.

Eq.7 can be also written as:

$$
\sigma v[p a]=9.8 \int R H O B \times 10^{3} \times \Delta(T V D) \times 0.3048 \times 101.3 \times 10^{3}
$$

Where RHOB is the density $\log$ is in $\left[\mathrm{g} / \mathrm{cm}^{3}\right]$ and $\Delta(\mathrm{TVD})$ is the incremental true vertical depth in [ft].

Then, the PP at selected depths were derived from the available RFT and static pressure reports.

Now, it is feasible to calculate the effective pressure according to the following equation, known as Terzaghi's equation, introduced by [15]:

$$
\sigma e f f=\sigma v-\alpha P p
$$

Where $P_{p}$ is the pore pressure, $\sigma v$ is the vertical stress and $\alpha$ is the Biot constant that is defined as the ratio of fluid volume gained (or lost) in a material element to the volume change of that elementand is considered 0.7 for carbonate rocks[16]. 
The estimated effective pressures were plotted against the Poisson's ratio (derived from different velocity correlations) and $V_{p} / V_{s}$. Note that, as suggested by [17],effective stress is exponentially related to the Poisson's ratio and $V_{p} / V_{s}$ according to Eq. 10:

$$
\sigma e f f=a \times e^{b x}
$$

Where $\sigma e f f$ is the effective stress, a and $\mathrm{b}$ are constants, and $\mathrm{x}$ is either Poisson's ratio or Vp/Vs.Eq.10 is specially handful to estimate the effective stress in case no RFT data is available.

The estimated Poisson's ratio and $V_{p} / V_{s}$ were imported into the model as input data, the effective pressure was modeled, and subsequently, pore pressure was predicted based on the Terzaghi's equation with a Biot coefficient of 0.7

The results of PP predictions were further compared to the real PP values extracted from available RFT data and the errors were determined from the following equation:

$$
\operatorname{Error}(\%)=\left(\frac{P P_{R F T}-P P_{\mathrm{mod}}}{P P_{\mathrm{mod}}}\right) \times 100
$$

Where $P P_{R F T}$ is the RFT reported pore pressure and $P P_{m o d}$ is the model predicted pore pressure.

\section{$3 \quad$ Results and discussion}

Based on the available bore reports, well A can be divided into two parts including an upper dominantly dolomite and a lower dominantly limestone sections, and Well B includes a mixed limestone and dolomite section.

Figure 1 shows the Reservoir Formation Test (RFT) data collected from Well A.

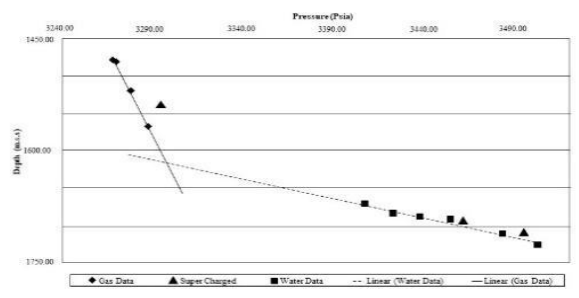

Fig. 1. Collected RFT data from Well A. 
In addition, due to lack of RFT report, static pressure data were collectedin nine points along the Well B (Figure 2).

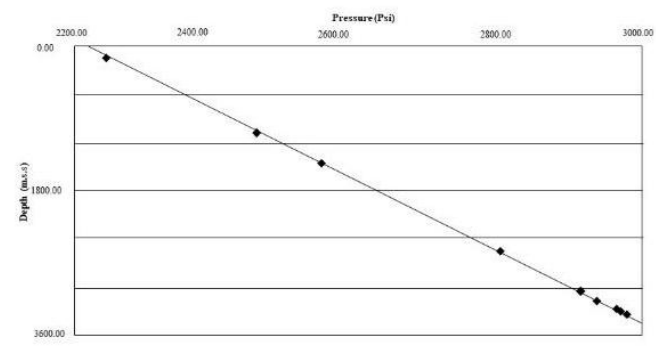

Fig. 2. Static pressure data vs. depth in well B.

It must be mentioned that since log and pore pressure data wereavailable from the depth of 2370 to 2525 meters and 0 to 2487 meters, respectively, it was only possible to apply the[17] model and determine the effective pressure in four points along the overlapped section.

\subsection{Vp and Vs estimations}

Figure 3 through Figure 6 present the results of $V_{p}$ and $V_{s}$ based on the DT log data and correlations developed by[12] and [13].

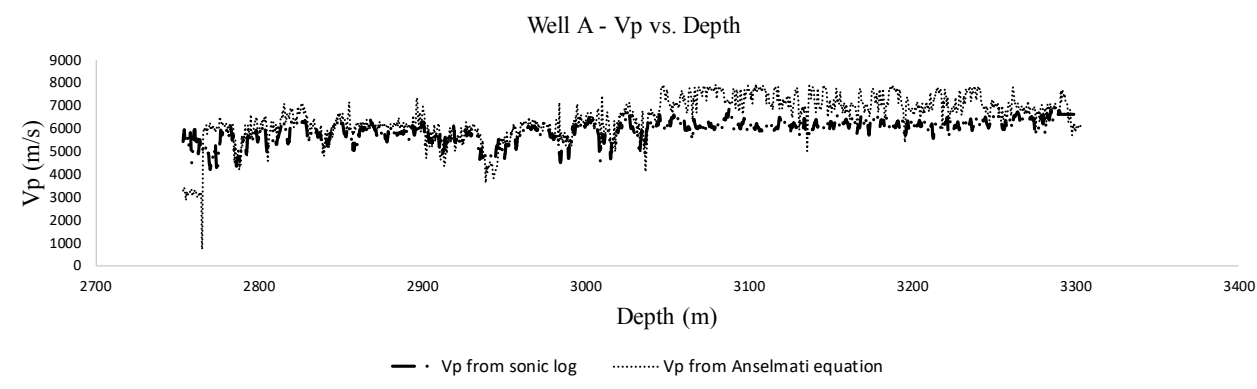

Fig.3. Variation of $V_{p}$, estimated from sonic log data and [13] equation, along the Well A.

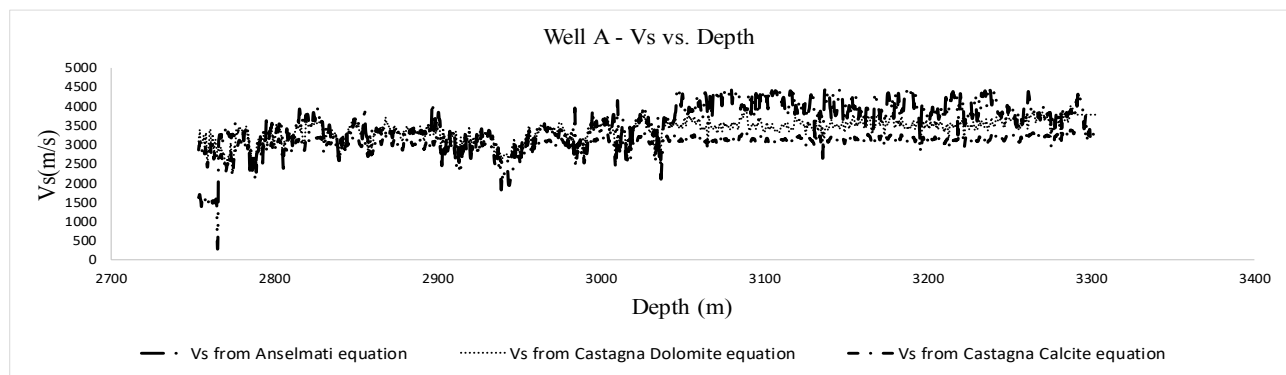

Fig.4.Variation of $V_{s}$, estimated from [13] and [12] equations, along the Well A. 


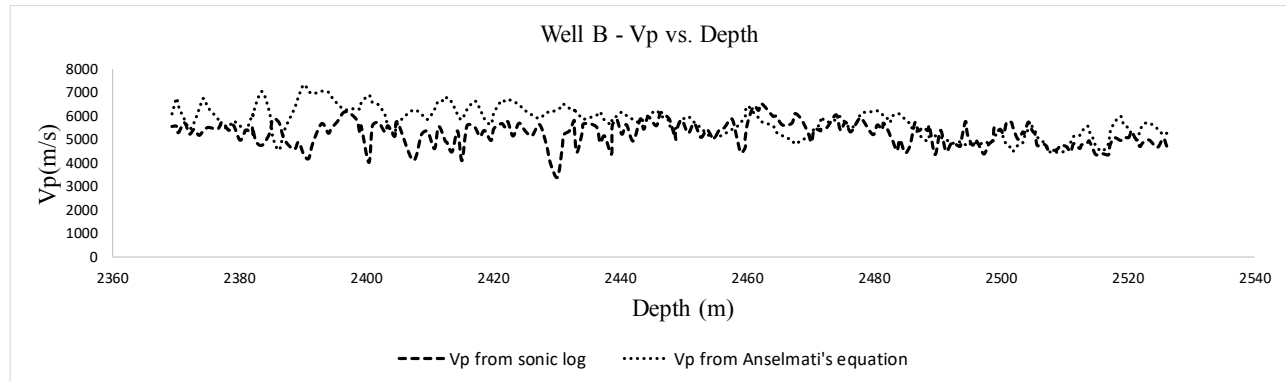

Fig.5. Variation of $V_{p}$, estimated from sonic log data and [13] equation, along the Well B.

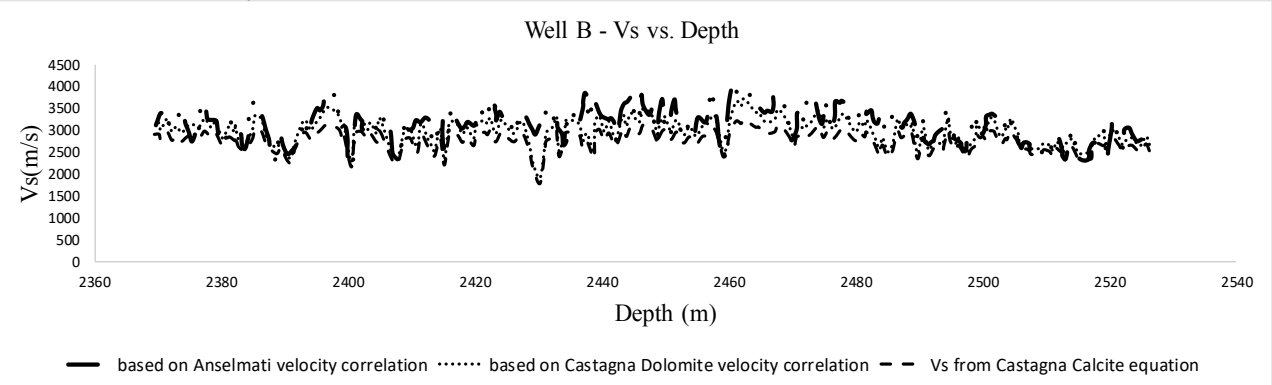

Fig.6.Variation of $V_{s}$, estimated from [13] and [12] equations, along the Well B.

\section{2 ratio \\ Effective pressure prediction based on dynamic Poisson's}

As listed in Table 2, the effective pressure was correlated to dynamic Poisson's ratio in Well A at ten selected points extracted from available RFT data.

Table 2. Correlation of effective pressure vs Poisson's ratio in well A.

\begin{tabular}{|c|c|c|}
\hline equation & $\mathrm{R}$-square & description \\
\hline Geff $=6.14270 \times 10^{4} e^{-6.63187 v}$ & $R^{2}=0.849787$ & $\begin{array}{l}\text { Effective pressure vs. Poisson's } \\
\text { ratioestimated from [13] equation. }\end{array}$ \\
\hline Geff $=1.55831 \times 10^{7} e^{-2.5885 \times 10 \times v}$ & $R^{2}=0.287175$ & $\begin{array}{l}\text { Effective pressure vs. Poisson's ratio } \\
\text { (estimated from [12] equation for } \\
\text { dolomite). }\end{array}$ \\
\hline$\sigma e f f=3.30448 \times 10^{3} e^{3.27704 v}$ & $R^{2}=0.259147$ & $\begin{array}{l}\text { Effective pressure vs. Poisson's ratio } \\
\text { (estimated from [12]equation for } \\
\text { calcite). }\end{array}$ \\
\hline
\end{tabular}

Moreover, the effective pressure was correlated to dynamic Poisson's ratio in Well B. 
Table 3.Correlation of effective pressure vs Poisson's ratio in well B.

\begin{tabular}{ccl}
\hline equation & \multicolumn{1}{c}{ R-square } & \multicolumn{1}{c}{ description } \\
\hline$\sigma e f f=7.48619 \times 10^{4} e^{-8.46212 v}$ & $R^{2}=0.904976$ & $\begin{array}{l}\text { Effective pressure vs. Poisson's } \\
\text { ratio estimated from [13] equation. }\end{array}$ \\
$\sigma e f f=3.34518 \times 10^{8} e^{-4.17198 \times 10 \times v}$ & $R^{2}=0.560710$ & $\begin{array}{l}\text { Effective pressure vs. Poisson's } \\
\text { ratio estimated from [12] equation } \\
\text { for dolomite. }\end{array}$ \\
$\sigma e f f=7.94111 \times 10^{2} e^{6.73234 v}$ & $R^{2}=0.481036$ & $\begin{array}{l}\text { Effective pressure vs. Poisson's } \\
\text { ratio estimated from [12] equation } \\
\text { for calcite. }\end{array}$
\end{tabular}

\subsection{Effective pressure prediction based on $\mathbf{V}_{\mathrm{p}} / \mathbf{V}_{\mathrm{s}}$}

As shown in Table 4 and 5, the effective pressure also was modeled based on the $V_{p} / V_{s}$ ratio that is significant to sense the effect of fluid type on PP prediction especially in Well A as a two phase (oil and gas) producer well. In general, Vs is more affected by the highly porous fabric of the low-velocity carbonates than $V_{p}[13]$ while [18] mentioned that pore-filled fluid type affect the dynamic Poisson's ratio.

Table 4.Correlation of effective pressure vs $V_{p} / V_{s}$ in well A.

\begin{tabular}{|c|c|c|}
\hline equation & R-square & description \\
\hline$\sigma e f f=5.15199 \times 10^{5} e^{-2.20141 x}$ & $R^{2}=0.845590$ & $\begin{array}{l}\text { Effective pressure vs. Vp/Vs } \\
\text { estimated from [13] equation. }\end{array}$ \\
\hline$\sigma e f f=6.45563 \times 10^{12} e^{-1.15990 \times 10 \times x}$ & $R^{2}=0.287704$ & $\begin{array}{l}\text { Effective pressure vs. Vp/Vs } \\
\text { estimated from[12] equation for } \\
\text { dolomite. }\end{array}$ \\
\hline$\sigma e f f=2.01149 \times 10^{3} e^{7.94124 \times 0.1 x}$ & $R^{2}=0.238501$ & $\begin{array}{l}\text { Effective pressure } \\
\text { Vp/Vsestimated from[12] } \\
\text { equation for calcite. }\end{array}$ \\
\hline
\end{tabular}

Table 5.Correlation of effective pressure vs $V_{p} / V_{s}$ in well B.

\begin{tabular}{ccl}
\hline equation & R-square & \multicolumn{1}{c}{ description } \\
\hline eeff $=9.19524 \times 10^{5} e^{-2.69795 x}$ & $R^{2}=0.917333$ & $\begin{array}{l}\text { Effective pressure vs. Vp/Vs } \\
\text { estimated from [13] equation. }\end{array}$ \\
Geff $=4.07968 \times 10^{16} e^{-1.67809 \times 10 \times x}$ & $R^{2}=0.562605$ & $\begin{array}{l}\text { Effective pressure vs. Vp / Vs } \\
\text { estimated from [12] equation for } \\
\text { dolomite. }\end{array}$ \\
\hline
\end{tabular}


Effective pressure vs. Vp / Vs
$\sigma e f f=1.76241 \times 10^{2} e^{1.88456 x}$
$R^{2}=0.467359$ calcite.

estimated from [12] equation for

\section{4}

\section{PP prediction using estimated effective pressure}

Figure 7 through Figure 10 present variations of the measured and predicted pore pressures along the target wells.

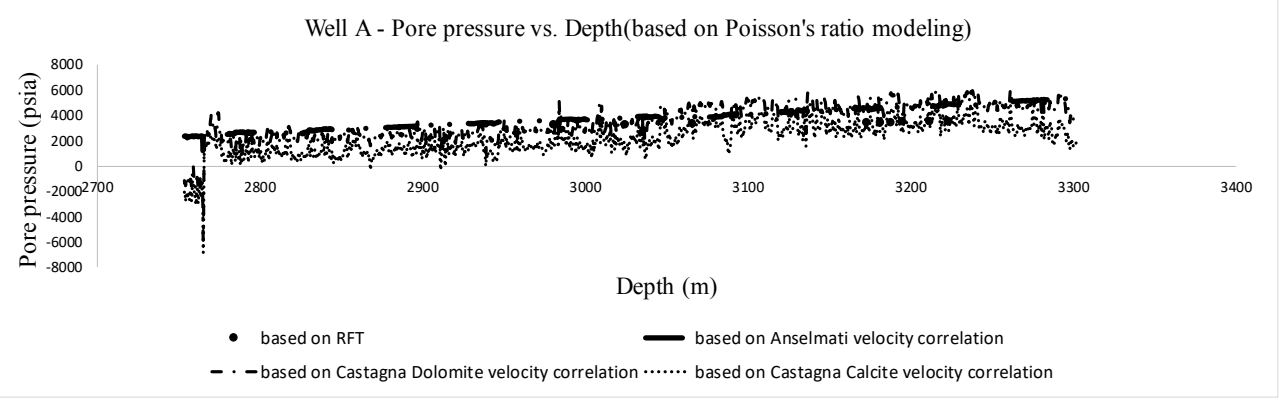

Fig.7.Variation of the reported pore pressures and the ones predicted based on the Poisson's ratio along Well A.

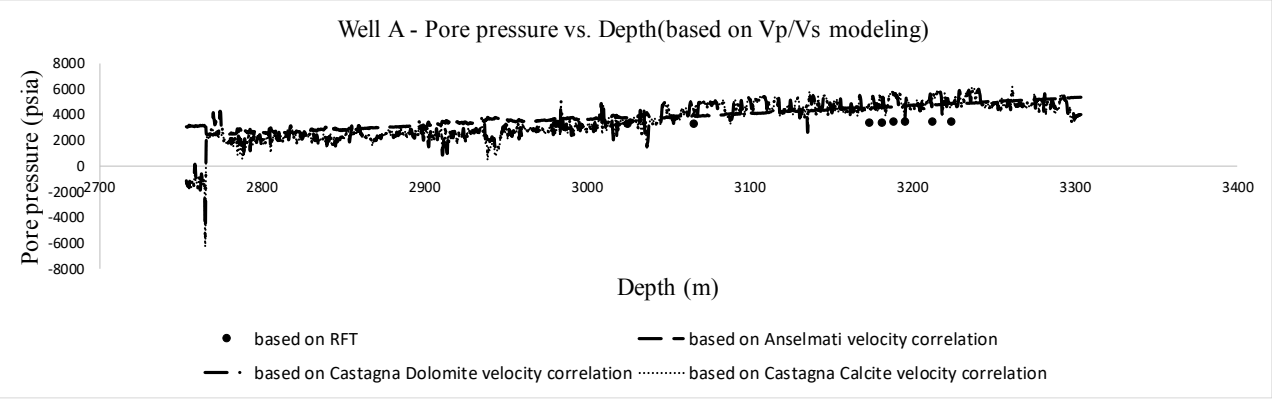

Fig.8.Variation of the reported pore pressures and the ones predicted based on the $V_{p} / V_{s}$ ratio along Well A.

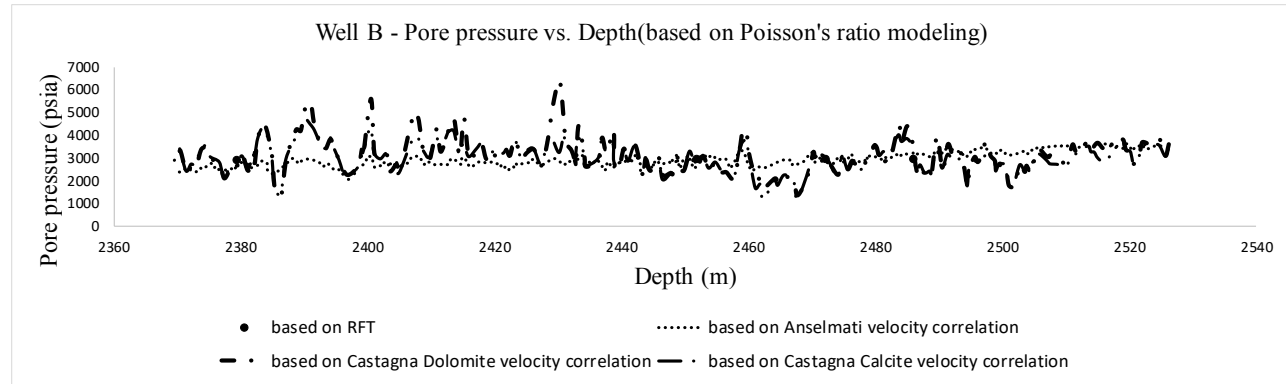

Fig.9.Variation of the reported pore pressures and the ones predicted based on the Poisson's ratio along Well B. 
Well B - Pore pressure vs. Depth(based on Vp/Vs modeling)

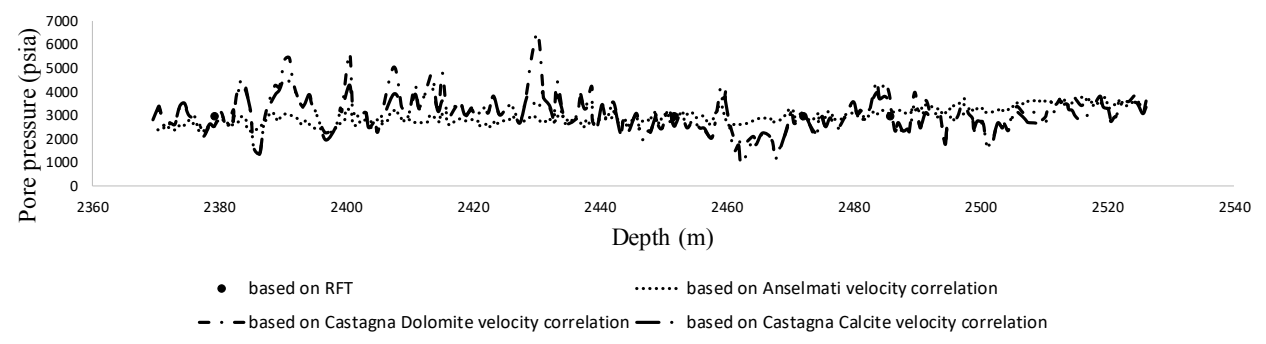

Fig.10.Variation of the reported pore pressures and the ones predicted based on the $V_{p} / V_{s}$ ratio along Well B.

\subsection{Error of PP predictions}

The results of error estimations are presented in Table 2, Table 3, Figure 11 and Figure 12.

Table 6. Estimated PP and relative errors in Well A.

\begin{tabular}{|c|c|c|c|c|c|c|c|}
\hline Depth & OVB & $\begin{array}{c}\text { Measure } \\
\text { d PP }\end{array}$ & PPP & $\begin{array}{l}\text { Misfit } \\
\text { PP }\end{array}$ & $\begin{array}{c}\text { Relativ } \\
\text { e } \\
\text { error }\end{array}$ & \multicolumn{2}{|c|}{ Methods } \\
\hline $\mathrm{m}$ & psia & psia & psia & psia & percent & & \\
\hline \multirow{6}{*}{$\begin{array}{c}2983.0 \\
5\end{array}$} & \multirow{6}{*}{$\begin{array}{c}10557.0 \\
0\end{array}$} & \multirow{6}{*}{3267.30} & $\begin{array}{c}2921.5 \\
6\end{array}$ & 345.74 & 10.58 & Anselmati & \multirow{3}{*}{$\mathrm{Vp} / \mathrm{Vs}$} \\
\hline & & & $\begin{array}{c}1881.0 \\
1\end{array}$ & $\begin{array}{c}1386.3 \\
0\end{array}$ & 42.43 & $\begin{array}{l}\text { Castagna } \\
\text { Dolomite }\end{array}$ & \\
\hline & & & $\begin{array}{c}1926.6 \\
3\end{array}$ & $\begin{array}{c}1340.6 \\
7 \\
\end{array}$ & 41.03 & $\begin{array}{c}\text { Castagna } \\
\text { Calcite }\end{array}$ & \\
\hline & & & $\begin{array}{c}2911.7 \\
6\end{array}$ & 355.54 & 10.88 & Anselmati & \multirow{3}{*}{$\begin{array}{c}\text { Poisson' } \\
\text { s ratio }\end{array}$} \\
\hline & & & $\begin{array}{c}1882.5 \\
6 \\
\end{array}$ & $\begin{array}{c}1384.7 \\
4 \\
\end{array}$ & 42.38 & $\begin{array}{l}\text { Castagna } \\
\text { Dolomite }\end{array}$ & \\
\hline & & & $\begin{array}{c}1927.7 \\
7\end{array}$ & $\begin{array}{c}1339.5 \\
3 \\
\end{array}$ & 41.00 & $\begin{array}{c}\text { Castagna } \\
\text { Calcite }\end{array}$ & \\
\hline \multirow{6}{*}{$\begin{array}{c}2985.7 \\
7\end{array}$} & \multirow{6}{*}{$\begin{array}{c}11170.2 \\
0\end{array}$} & \multirow{6}{*}{3269.28} & $\begin{array}{c}2765.4 \\
5 \\
\end{array}$ & 503.83 & 15.41 & Anselmati & \multirow{3}{*}{$\mathrm{Vp} / \mathrm{Vs}$} \\
\hline & & & $\begin{array}{c}3514.3 \\
5 \\
\end{array}$ & -245.07 & -7.50 & $\begin{array}{l}\text { Castagna } \\
\text { Dolomite }\end{array}$ & \\
\hline & & & $\begin{array}{c}3244.5 \\
9 \\
\end{array}$ & 24.69 & 0.76 & $\begin{array}{c}\text { Castagna } \\
\text { Calcite }\end{array}$ & \\
\hline & & & $\begin{array}{c}2796.2 \\
6\end{array}$ & 473.02 & 14.47 & Anselmati & \multirow{3}{*}{$\begin{array}{c}\text { Poisson' } \\
\text { s ratio }\end{array}$} \\
\hline & & & $\begin{array}{c}3508.9 \\
7\end{array}$ & -239.69 & -7.33 & $\begin{array}{l}\text { Castagna } \\
\text { Dolomite }\end{array}$ & \\
\hline & & & $\begin{array}{c}3318.5 \\
0\end{array}$ & -49.22 & -1.51 & $\begin{array}{c}\text { Castagna } \\
\text { Calcite }\end{array}$ & \\
\hline \multirow{3}{*}{$\begin{array}{c}3026.8 \\
8\end{array}$} & \multirow{3}{*}{11596} & \multirow{3}{*}{3277.83} & $\begin{array}{c}2884.7 \\
2 \\
\end{array}$ & 393.11 & 11.99 & Anselmati & \multirow{3}{*}{$\mathrm{Vp} / \mathrm{Vs}$} \\
\hline & & & $\begin{array}{c}2415.7 \\
7\end{array}$ & 862.06 & 26.30 & $\begin{array}{l}\text { Castagna } \\
\text { Dolomite }\end{array}$ & \\
\hline & & & $\begin{array}{c}2294.6 \\
3\end{array}$ & 983.20 & 30.00 & $\begin{array}{c}\text { Castagna } \\
\text { Calcite }\end{array}$ & \\
\hline
\end{tabular}




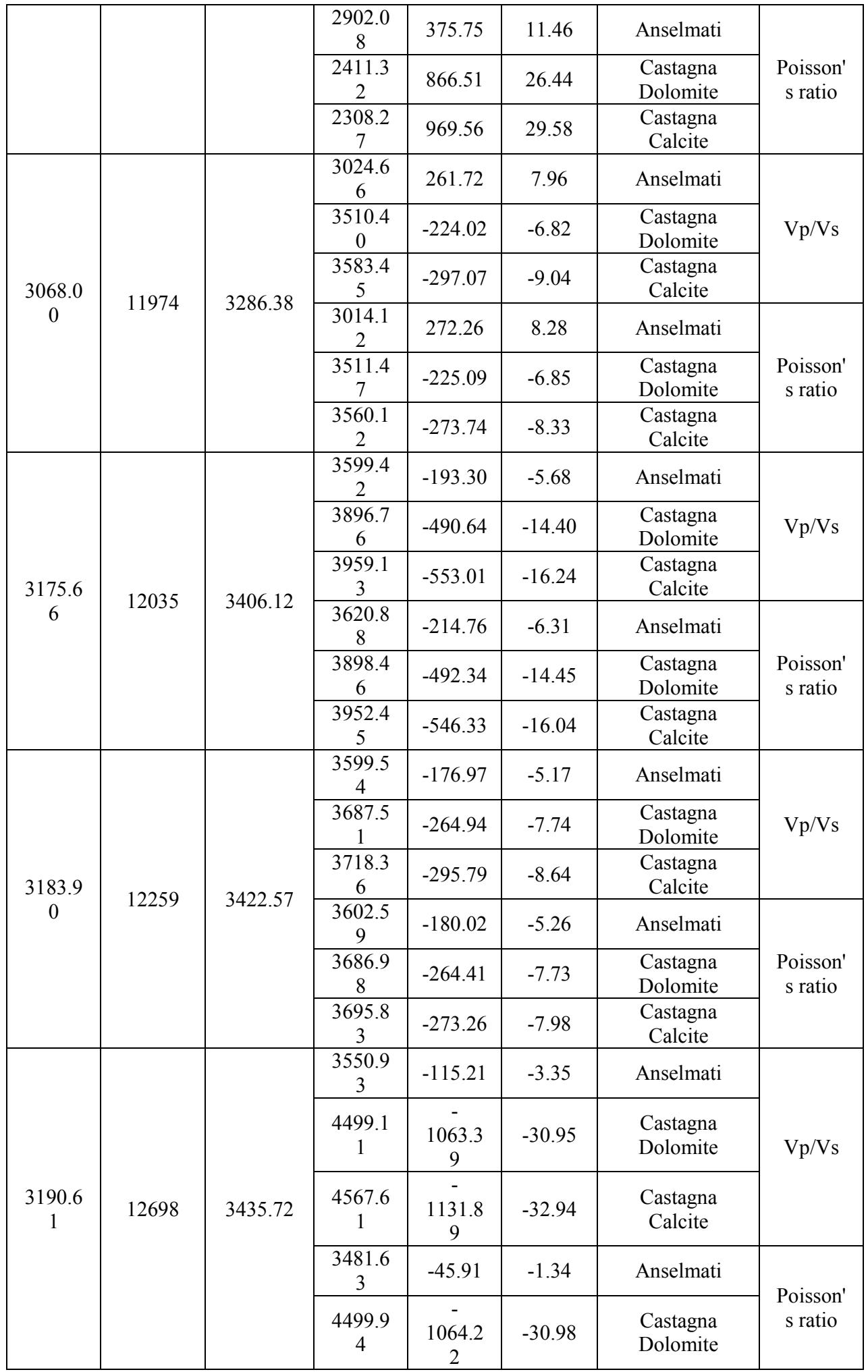




\begin{tabular}{|c|c|c|c|c|c|c|c|}
\hline & & & $\begin{array}{c}4543.2 \\
6\end{array}$ & $\begin{array}{c}- \\
1107.5 \\
4\end{array}$ & -32.24 & $\begin{array}{l}\text { Castagna } \\
\text { Calcite }\end{array}$ & \\
\hline \multirow{6}{*}{$\begin{array}{c}3197.6 \\
2\end{array}$} & \multirow{6}{*}{11109} & \multirow{6}{*}{3453.16} & $\begin{array}{c}3882.3 \\
0\end{array}$ & -429.14 & -12.43 & Anselmati & \multirow{3}{*}{$\mathrm{Vp} / \mathrm{Vs}$} \\
\hline & & & $\begin{array}{c}2831.2 \\
2\end{array}$ & 621.94 & 18.01 & $\begin{array}{l}\text { Castagna } \\
\text { Dolomite }\end{array}$ & \\
\hline & & & $\begin{array}{c}2835.4 \\
2 \\
\end{array}$ & 617.74 & 17.89 & $\begin{array}{c}\text { CastagnaCalcit } \\
\mathrm{e}\end{array}$ & \\
\hline & & & $\begin{array}{c}3791.0 \\
0\end{array}$ & -337.84 & -9.78 & Anselmati & \multirow{3}{*}{$\begin{array}{c}\text { Poisson' } \\
\text { s ratio }\end{array}$} \\
\hline & & & $\begin{array}{c}2832.1 \\
7\end{array}$ & 620.99 & 17.98 & $\begin{array}{l}\text { Castagna } \\
\text { Dolomite }\end{array}$ & \\
\hline & & & $\begin{array}{c}2851.3 \\
9\end{array}$ & 601.77 & 17.43 & $\begin{array}{c}\text { Castagna } \\
\text { Calcite }\end{array}$ & \\
\hline \multirow{6}{*}{$\begin{array}{c}3214.7 \\
0\end{array}$} & \multirow{6}{*}{12215} & \multirow{6}{*}{3482.76} & $\begin{array}{c}3773.3 \\
6\end{array}$ & -290.60 & -8.34 & Anselmati & \multirow{3}{*}{$\mathrm{Vp} / \mathrm{Vs}$} \\
\hline & & & $\begin{array}{c}4124.4 \\
7 \\
\end{array}$ & -641.71 & -18.43 & $\begin{array}{l}\text { Castagna } \\
\text { Dolomite }\end{array}$ & \\
\hline & & & $\begin{array}{c}4190.7 \\
9 \\
\end{array}$ & -708.03 & -20.33 & $\begin{array}{c}\text { Castagna } \\
\text { Calcite }\end{array}$ & \\
\hline & & & $\begin{array}{c}3857.2 \\
8 \\
\end{array}$ & -374.52 & -10.75 & Anselmati & \multirow{3}{*}{$\begin{array}{c}\text { Poisson' } \\
\text { s ratio }\end{array}$} \\
\hline & & & $\begin{array}{c}4126.1 \\
8 \\
\end{array}$ & -643.42 & -18.47 & $\begin{array}{l}\text { Castagna } \\
\text { Dolomite } \\
\end{array}$ & \\
\hline & & & $\begin{array}{c}4181.8 \\
8\end{array}$ & -699.12 & -20.07 & $\begin{array}{l}\text { Castagna } \\
\text { Calcite }\end{array}$ & \\
\hline \multirow{6}{*}{$\begin{array}{c}3226.2 \\
9\end{array}$} & \multirow{6}{*}{12171} & \multirow{6}{*}{3501.84} & $\begin{array}{c}3842.5 \\
7\end{array}$ & -340.73 & -9.73 & Anselmati & \multirow{3}{*}{$\mathrm{Vp} / \mathrm{Vs}$} \\
\hline & & & $\begin{array}{c}3636.4 \\
0\end{array}$ & -134.56 & -3.84 & $\begin{array}{l}\text { Castagna } \\
\text { Dolomite }\end{array}$ & \\
\hline & & & $\begin{array}{c}3686.2 \\
8\end{array}$ & -184.44 & -5.27 & $\begin{array}{c}\text { Castagna } \\
\text { Calcite }\end{array}$ & \\
\hline & & & $\begin{array}{c}3865.9 \\
2\end{array}$ & -364.08 & -10.40 & Anselmati & \multirow{3}{*}{$\begin{array}{l}\text { Poisson' } \\
\text { s ratio }\end{array}$} \\
\hline & & & $\begin{array}{c}3636.4 \\
9\end{array}$ & -134.65 & -3.85 & $\begin{array}{l}\text { Castagna } \\
\text { Dolomite }\end{array}$ & \\
\hline & & & $\begin{array}{c}3661.7 \\
5\end{array}$ & -159.91 & -4.57 & $\begin{array}{c}\text { Castagna } \\
\text { Calcite }\end{array}$ & \\
\hline
\end{tabular}



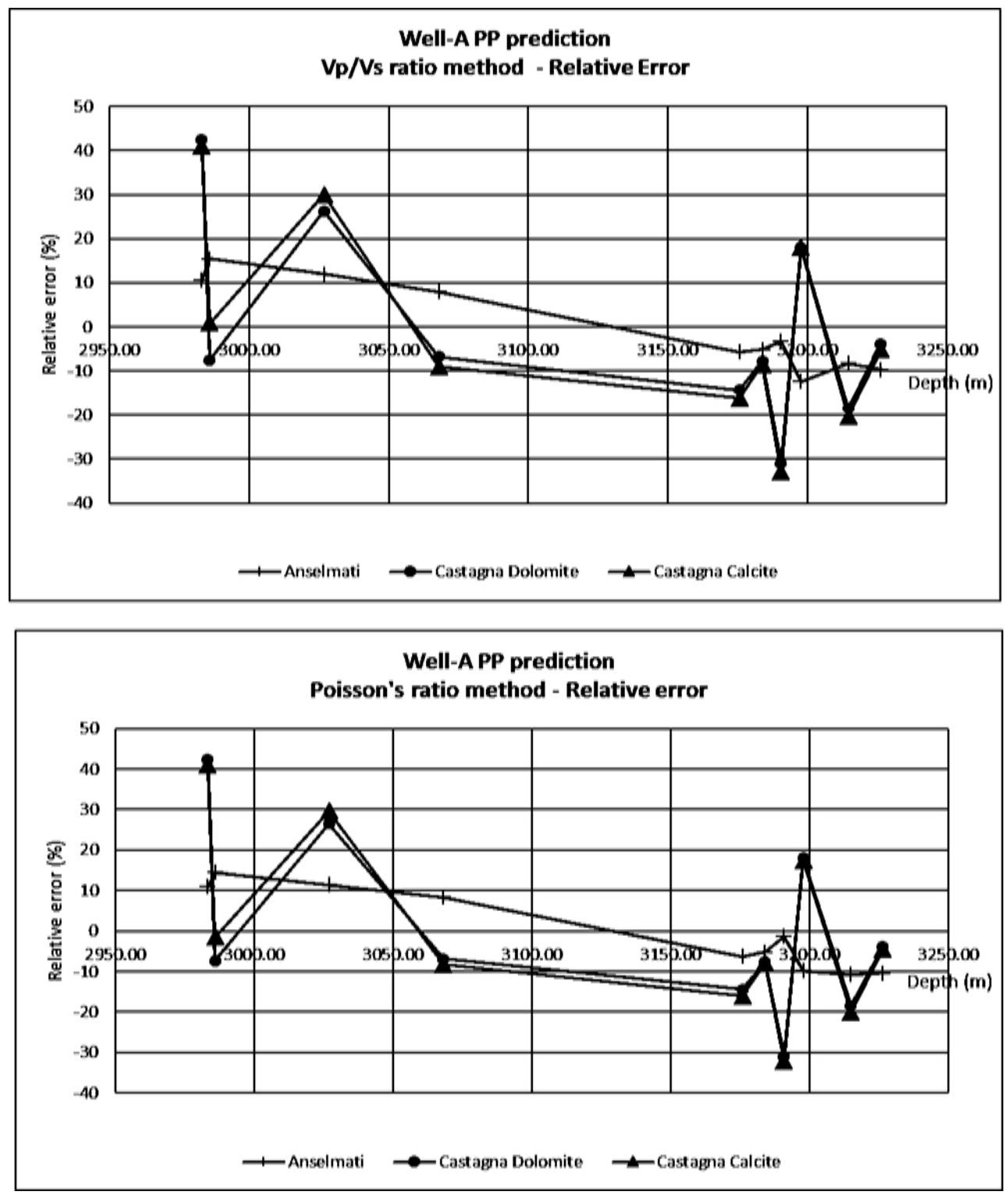

Fig. 11: Relative error of PP prediction in Well A. 
Table 7. Estimated PP and relative errors in Well B.

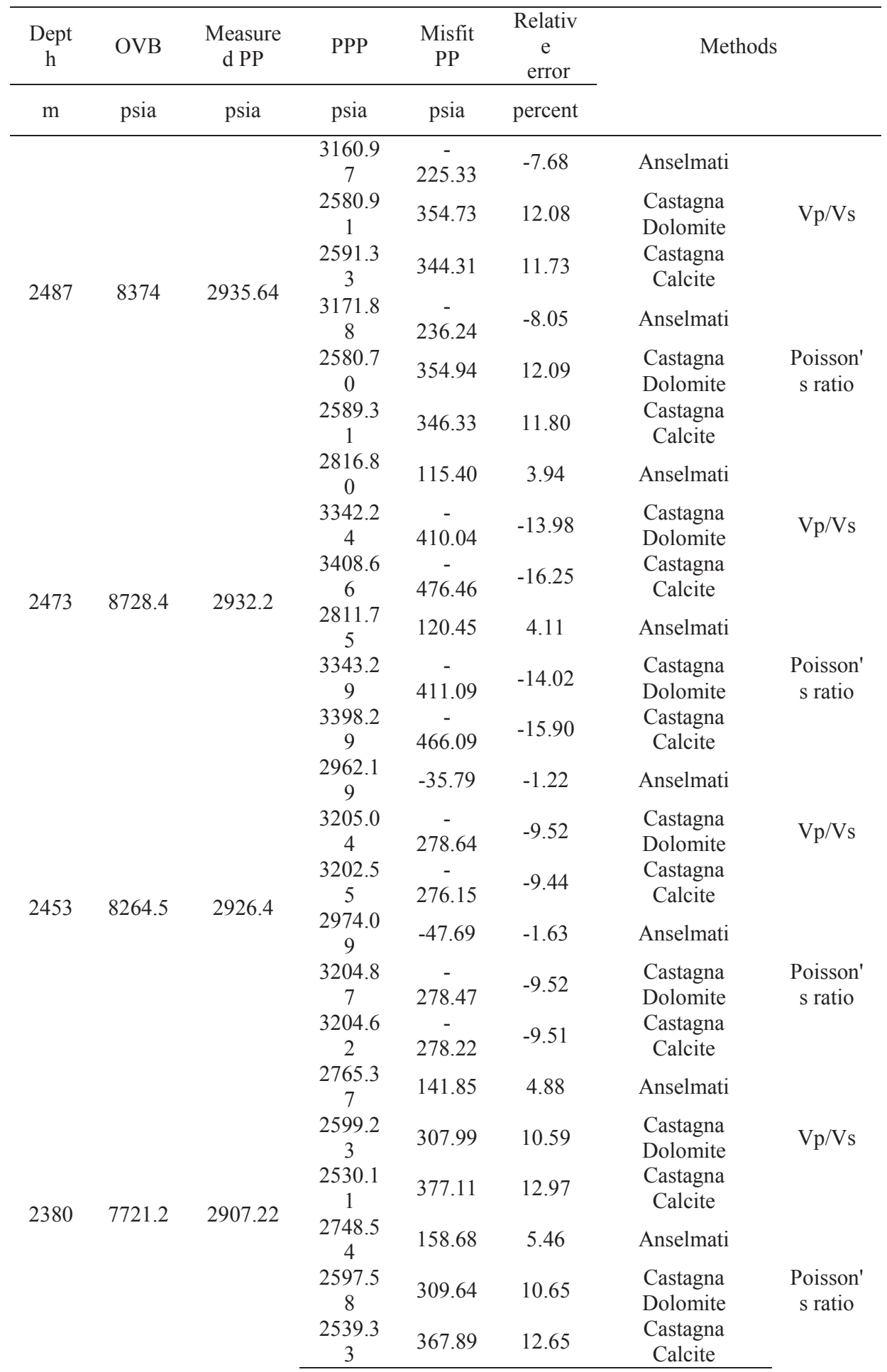



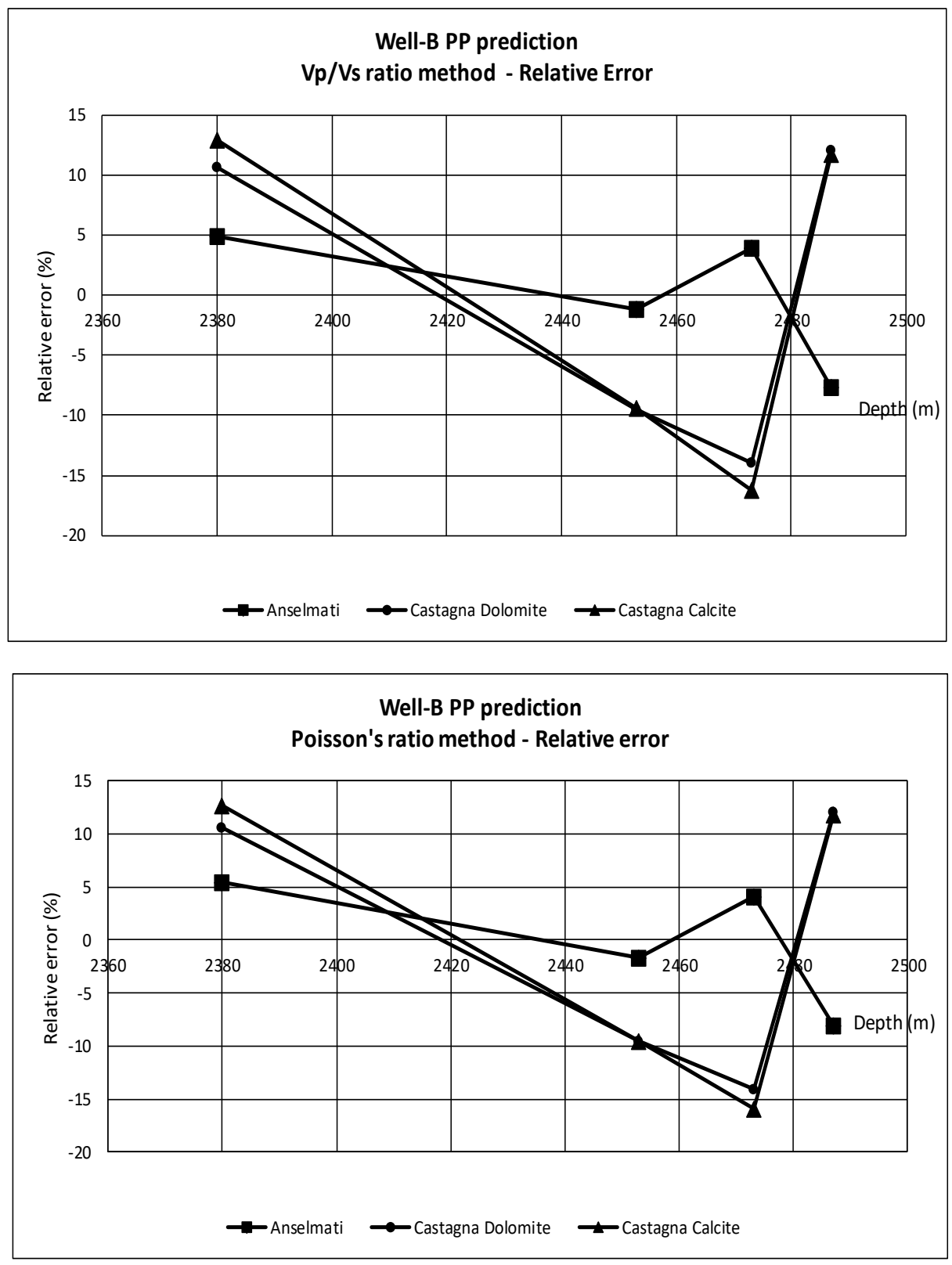

Fig. 12. Relative error of PP prediction in Well B.

Overall, the best results for PP prediction were achieved in well B. Moreover, it is deemed that calculations based on [13] and [12]dolomite correlations could help to properly predict the PP while calculations based on [12]calcite correlation was more effective only in lower depth of well A. The errors associated with the results of PP prediction based on $V_{p} / V_{s}$ in well A could be due to the presence of gas. 


\subsection{Conclusions}

During the present study, elastic moduli effective stress (PE)-relation method was revealed to be efficient for Pore Pressure (PP) prediction in carbonates mainly due to the lack of relationship between porosity and compaction in this type of rocks. However, the effect of lithology and fluid type must be accounted for, especially, in selection of a proper velocity estimation correlation. Moreover, dynamic elastic moduli parameters were estimated based on dynamic data instead of static parameters which are generally more realistic and lower than the corresponding dynamic data due to the effect of pore pressure, cementation, stressstrain rate and amplitude.

The dynamic Poisson's ratio is specifically recommended to be applied in case of gas reservoirs while it has been revealed that Biot's coefficient of 0.7 can be effectively used in Terzaghi's effective stress law for the case of carbonate reservoirs.

The Castagna model works effectively for the case of well A with a dominant lithology of limestone in the lower part overlaid by a dominantly dolomite section. In addition, the Anselmati model could predict properly as well in upper part of well A and the whole section of well B.

At the end, the methods discussed in this study have some main advantages, such as, they are purely based on mechanics and so not restricted to the mechanisms of abnormal PP and as a result the process of calculation is not complicated.

We are thankful to the South Zagros Oil and Gas Production Company (SZOGPC) and Shiraz University for all their support.

\section{References}

1. C. M. Sayers,G. M. Johnson, G.Denyer Pore pressure prediction from seismic tomography, Proceedings of the Annual Offshore Technology Conference,1(1), 173179 (2000).

2. N. C. Dutta Geopressure prediction using seismic data: Current status and the road ahead,Geophysics,67(6), 2012-2041 (2002).

3. M. D. Zoback Book Reservoir Geomechanics. (Cambridge University Press. 2007).

4. J. B.Foster, H. E. Whalen Estimation of formation pressures from electrical surveys Offshore Louisiana,SPE Reprint Series,(49), 57-63 (1966).

5. J. P. Mouchet, A.MitchellAbnormal Pressures While Drilling. (Boussens, France, Elf Aquitaine.1989).

6. B.EatonThe Equation for Geopressure Prediction from Well Logs. (in Proceedings of Fall Meeting of the Society of Petroleum Engineers of AIME. Society of Petroleum Engineers.1975).

7. J. Zhang Effective stress, porosity, velocity and abnormal pore pressure prediction accounting for compaction disequilibrium and unloading, Marine and Petroleum Geology, 45, 2-11 (2013).

8. C. Sayers, R. Latimer An introduction to this special section: Carbonates,Geophysics 20(1), (2008).

9. S.Chopra, A. R. Huffman Velocity determination for pore-pressure prediction, Leading Edge (Tulsa, OK),25(12), 1502-1515 (2006).

10. Z.Wang, R.Wang Pore pressure prediction using geophysical methods in carbonate reservoirs: Current status, challenges and way ahead, Journal of Natural Gas Science and Engineering,27, 986-993 (2015). 
11. V.Atashbari, M.Tingay Pore pressure prediction in carbonate reservoirs, SPE Latin American and Caribbean Petroleum Engineering Conference Proceedings, 1, 4362(2012).

12. J.Castagna,M.Batzle, T. Kan, M.Backus Offset-Dependent Reflectivity-Theory and Practice of AVO Analysis, Offset-Dependent Reflectivity-Theory and Practice of AVO Analysis. (Society of Exploration Geophysicists.1993).

13. F. S. Anselmetti,G. P. Eberli Controls on sonic velocity in carbonates, Pure and Applied Geophysics PAGEOPH,141(2-4), 287-323.

14. A. R.Najibi, M.Ghafoori,G. R. Lashkaripour,M. R.AsefReservoir geomechanical modeling: In-situ stress, pore pressure, and mud design, Journal of Petroleum Science and Engineering, 151, 31-39 (2017).

15. K.Terzaghi,P. B.Ralph, M.GholamrezaSoil mechanics in engineering practice (1996).

16. M. A. Biotl, D. G. Willis Theory of consolidation, Developments in Geotechnical Engineering,48(C), 324-422 (1989).

17. L.Qiuguo, H.Denis., Z.Liangxiao, C. Yuxin Abnormal Pressure Detection and Wellbore Stability Evaluation in Carbonate Formations of East Sichuan, China, IADC/SPE Drilling Conference(2000).

18. W.Zhu, W.Yu, K.Li Formation pressure prediction in carbonate, in Beijing 2009 International Geophysical Conference and Exposition, Society of Exploration Geophysicists 153-153 (2009). 